\title{
Forum
}

Members of the association are invited to submit letters, typed and double-spaced, commenting on articles published in $P M L A$ or on matters of general scholarly or critical interest. Footnotes are discouraged, and letters of more than one thousand words will not be considered. Decision to publish and the right to edit are reserved to the editor, and the authors of the articles discussed will be invited to reply.

\section{The Arabic Frame Tradition}

To the Editor:

I would like to offer some corrections to Katharine Slater Gittes' article "The Canterbury Tales and the Arabic Frame Tradition" (PMLA 98 [1983]: 237-51). Gittes betrays her unfamiliarity with basic scholarship on the history of the Panchatantra. Her first error is the belief that "a subsequent translation from the Arabic back into Sanskrit forms the basis of all the existing Sanskrit texts," and a second is her claim that "the Arabs, not the Indians, first enclosed this collection within a frame" (237). The former statement would have shocked even such early students of the Panchatantra as Johannes Hertel or Franklin Edgerton and others before them, who knew as early as the beginning of the century of several Sanskrit recensions of the Bidpai collection, none of which is a reverse translation from the Arabic.

Unfortunately, Gittes bases a large part of her argument on the latter statement, attempting to prove that the open-ended framing device that Chaucer borrowed from oriental sources is a reflection of Arab mentality. Her belief that the Arabs first enclosed the Panchatantra in a frame rests on a surmise made by B. E. Perry in The Origin of the Book of Sindbad (Berlin: W. de Gruyter, 1960), where he refers to a similarity between the introduction to the Book of Sindbad and that of the Panchatantra. Perry offers, without any tangible support, the opinion that the introduction to the Panchatantra originated in the Book of Sindbad (54). The latter work, as Perry himself concludes, is Pahlavi in origin, and even if it did provide a model for the introduction to the Panchatantra, it does not follow that the Arabs were the first to enclose the Panchatantra in a frame. It is well known that the Arabs learned the framing device from the Indians through the intermediary of Persians and transmitted it to the West through a flux of important oriental narratives, among which is the Book of Kalilah wa Dimnah. That the framing device originated in India was recognized by scholars writing as early as the nineteenth century, such as the Indologist A. Loiseleur-Deslongchamps in his Essai sur les fables indiennes et sur leur introduction en Europe (Paris: Techener, 1838), 6-7. And the fact that the Panchatantra was framed in its Sanskrit sources from the earliest stages has been supported by modern scholars such as S. K. De ("From Aśvaghosa to Kālidāsa," in A History of Sanskrit Literature: Classical Period, ed. S. N. Dasgupta, 2nd ed. [Calcutta: Univ. of Calcutta, 1962], 86-87). Finally, it should be noted that the Arabs added an introduction or a frame to Kalilah wa Dimnah two centuries after it was translated into Arabic. This introduction, entitled "The Preface of Ali the Son of ash-Shah Farisi," is found only in some later editions of the book; it is found in neither the oldest versions nor the older translations. It differs from the Sanskrit introduction to the Panchatantra in both content and length.

Contrary to the thrust of Gittes' argument, the Arabic frame of Kalilah wa Dimnah is not open-ended. In this respect it differs from the introduction to the Panchatantra, which contains nothing to indicate that Vishunsharman's instruction to the princes has been completed at the close of the work. In all relevant Arabic editions of Kalilah wa Dimnah the narrator closes the frame after the last tale with an expression of good wishes addressed to King Dabshalim. It seems that Gittes is unaware of the existence of this Arabic frame. Ironically, she derives her information about the Arabic version of Kalilah wa Dimnah only from Arthur Ryder's translation of the well-known Sanskrit Pūrnabhadra recension of the Panchatantra (A.D. 1199) edited in the original by Johannes Hertel and published at Harvard University in 1908 . Gittes would have done better simply to stress the positive role of the Arabs in transmitting the framing device to the West without claiming for them a priority that runs counter to the accepted scholarship in the field.

\section{IBRAHIM DAWOOD Yarmouk University Irbid, Jordan}

\section{To the Editor:}

Katharine Slater Gittes' essay perpetuates the more common myths about the "Arab mind" and Arabic literary aesthetics. While Chaucerians may debate the extent to which Eastern framing techniques influenced Chaucer (Gittes' discussion does little more than recapitulate material presented in Dorothee Metlitzki's 
The Matter of Araby in Medieval England), I am concerned with the portions of her essay in which she attempts to draw far-reaching conclusions concerning Arabic literature.

The essay's confused historical perspective (is preIslamic [sixth- and seventh-century] Arabic poetry "medieval"?) is exemplified by the use of the term "Arabic" not merely "to include the work of Persians and others writing in Arabic under the aegis of the caliphs" $(250$, n. 2$)$-that is, for post-Islamic literaturebut to refer to the Panchatantra. This title, however, designates not an "eighth-century Indian-Arabic work" (237) but a fifth-century Sanskrit collection of fables that was translated into Pahlavi in the sixth century and thence into Arabic, around 750, by Ibn al-Muqaffa', as Kalilah wa Dimnah. The latter work (and others like it) introduced the technique of the frame story into Arabic literature; it is erroneous to assert that this technique "originated and developed in Arabia" (237) around "Bedouin campsites" (250). Its Indo-Iranian origin is attested to by Keith, who states (as paraphrased by Gittes 238) that "the insertion of tales within tales [is] a characteristic of Indian collections."

The doubtful validity of extrapolating generalizations about mathematics to literature is increased when these generalizations themselves lack sufficient foundation. Babylonian influence on pre-Islamic Arab mathematics was limited; in post-Islamic times, the Arabs drew on sources ranging from Greek (both Euclidean and Pythagorean) to Indian. The suggestion that "the Arabs felt more comfortable than the Greeks with infinite series and limitless chains" (240) is, to say the least, unscientific (the relation of comfort to mathematical theory or practice is unclear); moreover, the assumption that lies at the heart of Gittes' thesis-that Arabs perceive numbers differently than do Westerners, reading them (as they do their script) from right to left and hence comprehending first the smaller units and then the larger ones-confuses conventions of writing with comprehension. In fact, numbers written as numerals are (like our own "arabic" numerals) written from left to right, and numbers spelled out are understood in terms of their numerical sense.

Gittes' observations on Arabic literature rely largely on outdated sources, such as Lyall and Nicholson: the falsity of traditional assumptions regarding the structural "incoherence" of Arabic poetry has been amply demonstrated by a number of recent studies of which Gittes appears to be unaware. The erroneous opinion that the "topics discussed" in the qasidah are "rarely, if ever, linked to one another," like the judgment that it possesses "no central unifying theme that penetrates each line" (240) and therefore exhibits "lack of an overall principle of organization" (241), represents a misguided attempt to apply Coleridgean standards of "organic unity" to medieval poetry. The syntactic independence of the line, and the resulting parataxis, does not preclude the existence of overall structural patterns; moreover, the medieval Arab rhetoricians constantly reiterated the necessity for observing a "wellproportioned and harmonious balance of parts" (239) in the poem.

Gittes also fails to distinguish among the various forms and genres of Arabic literature: the pre-Islamic lyric ode and its post-Islamic developments, the Koran (which to the Muslim is Scripture, not "the thoughts and experiences" of the Prophet [242]), Hadith literature (prophetic tradition, not a "companion piece" to the Koran [242] but a source of religious law, and in any case not a literary composition), adab literature, the maqamah (or picaresque novella in rhymed prose), biography, history, and travel literature- though she makes little mention of works that are, in spirit and structure, closer to Kalilah wa Dimnah, such as Sinbad and the Thousand and One Nights. Moreover, arguing that "all later Arabic literature" is measured by the qasidah (242) is no more valid than maintaining that all post-Renaissance European literature is measured by the sonnet.

Gittes also appears to misunderstand the nature of framing devices themselves. A frame may function as an authenticating device (as Morton Bloomfield has shown with reference to Chaucer) or as an organizing principle; these functions may or may not be combined. The first characterizes Kalilah wa Dimnah, which was intended not to unfold a plot or treat us to examples of rich characterization but to provide moral instruction; the second informs such works as Sinbad and the Nights, which are unified not only by their protagonist or storyteller but by the overall, enclosing structural pattern of ring composition, also found in the maqamah and in medieval Persian verse romance (as well as in lyric poetry). The authenticating function of frames in narrative is analogous but not identical to the similar function performed by eyewitness accounts in historical or pseudohistorical literature; and while the same function is often performed by the first-person speaker in the lyric, this does not make a speaker equivalent to a frame. Gittes, however, treats any frame as if it functioned uniformly and any first-person account (or lyric persona) as a frame.

Other, minor points can be mentioned only briefly. The excessive stress on "influence" reflects the kind of assumption that (as G. E. von Grunebaum has pointed out) we should be chary about making with respect to traditions that are, after all, so closely related. The architectural analogy between mosque and cathedral ignores both the disparate styles identified for the latter and the strong focus of the former around its central courtyard, its symbolic as well as functional heart. Assumptions about the "atomistic" Arab worldview, extended to aesthetics and to theories of composition, have been shown to be of little validity even in a narrow religious context. "Medieval concepts ... of 
wholeness and coherence" (249), which (in both Christianity and Islam) are based largely on an analogical conception of cosmic harmony and order (as Jordan's remarks indicate), are quite different from either Aristotelian or Coleridgean concepts of unity, both of which are inappropriate, indeed irrelevant, to medieval literature. "Emphasis on the unit" (244) is not restricted to Islamic literature, as a glance at, for example, the medieval technique of laisse composition demonstrates; such "units" are simultaneously given individual emphasis and manipulated into ordered and coherent wholes. The "Western tendency to finish things" (249) is hardly manifest in such works as the Charrette or the Roman de la rose (to say nothing of the Poetics or Christabel): do such works reflect an oriental influence? Ethnic origin is hardly an objective criterion in literary scholarship.

Essays like Gittes' demonstrate the unwisdom of dependence on secondary sources of dubious reliability and the need for a systematic study, based on sound methods of scholarship, of the relevant texts in their original languages.

\section{Julie Scott Meisami}

Berkeley, California

\section{Reply:}

Ibrahim Dawood raises some interesting points in a cogent fashion. Unfortunately, as often happens in critical controversy, the main issue devolves into a conflict between authorities who have done the textual and historical spadework. The hypothesis offered by B. E. Perry, far from being a fragile "surmise . . . without any tangible support," is a detailed, coherent account that thoroughly refutes the claims of pioneer Indologists regarding the origins of the frame narrative. In spite of the brilliance of such earlier scholars as Hertel, Edgerton, and Loiseleur-Deslongchamps, I believe that Perry's hypothesis, drawing as it does on nearly half a century of intervening scholarship, convincingly counters these earlier critics (and their modern followers) by indicating that western Asia, not India, is the "original nursery" of "paratactic arrangement of stories on one frame" and that the Arabs, or Near Easterners, not the Indians, first placed a frame around the Panchatantra $(25,54)$. Perry's hypothesis is more persuasive than the views of these other critics because it resolves issues that cannot be resolved otherwise.

My statement that "a subsequent translation from the Arabic back into Sanskrit forms the basis of all the existing Sanskrit texts" is indeed categorical. I make this statement, however, because I am persuaded by Perry's meticulously constructed argument that the form of all extant texts containing the prologue comes from a reverse translation, that the Panchatantra's introduction originated in the Book of Sinbad and "migrated eastward from Persian or Muslim territory into India," where it was incorporated into the Panchatantra (54). This argument seems to me a more reasonable construction of the facts than any other argument of which I am aware, though it is nonetheless true that we can never know with certainty the exact form of the earliest version of the introduction to the Panchatantra, a work rewritten so many times that there are many related forms with striking textual similarities. It would have been more prudent to say that the introduction to the main forms of the Panchatantra is most likely a reverse translation from Arabic and that the Ryder translation, derived from Arabic intervention, probably typifies the earliest translations (as Franklin Edgerton would agree; see The Panchatantra Reconstructed [New Haven: American Oriental Society, 1924], 2: 15, et passim).

Though Dawood is correct that several centuries later the Arabs added an introduction or frame to Kalilah wa Dimnah and though this preface differs from the Sanskrit introduction to the Panchatantra, I do not discuss this later Arabic work because it is a further variation of the Panchatantra and has nothing to do with the stage of development I talk about in my essay. Moreover, any narrator's or author's assertion that a narrative is finished, as occurs in some frame narratives, including the Canterbury Tales, does not necessarily mean that the work is, in fact, "closed"; "openendedness," or perhaps "openness," as I define it in my essay, is a matter of total structural logic, quite apart from any attached epilogue, and can be suggested by elements within the total structure as well as at the end.

Julie Scott Meisami's objections seem to be less substantial. In using the word "Arabic" to cover groups of people who wrote in Arabic but who were not Arabs, I follow most other scholars (see, e.g., Philip K. Hitti, History of the Arabs, 7th ed. [London: Macmillan, 1960], 240). Meisami also fails to make the important distinction between the outer framing story and the boxing of tales within the framing story. I claim that the former is Near Eastern and the latter Indian. In the passage I cite, Keith is discussing the boxing of tales, not the framing story. The edition of the Panchatantra to which I refer in my essay has both an Arabic frame and Indian boxing tales.

For Babylonia as the starting point of both Greek and Arabic mathematics, see B. L. van der Waerden, Science Awakening, trans. Arnold Dresden (Groningen: Noordhoff, 1954), 1: 280. Meisami actually verifies my position on numerals, because if Arabic numerals are written in Western fashion and then read from right to left, the reader will arrive at the units first, before moving on to the whole.

I cannot answer Meisami's charge that I am unaware of "a number of recent studies" of Arabic poetry because she does not divulge what these studies are. Likewise, it is difficult to comment on the unnamed "medieval Arab rhetoricians." One rhetorician who 